\title{
The Social Science of Democracy?
}

\section{Citation}

Welch, Cheryl. 2011. The social science of democracy? Perspectives on Politics 9, no. 2: 371-374.

\section{Published Version}

doi:10.1017/S1537592711000387

\section{Permanent link}

http://nrs.harvard.edu/urn-3:HUL.InstRepos:11204672

\section{Terms of Use}

This article was downloaded from Harvard University's DASH repository, and is made available under the terms and conditions applicable to Other Posted Material, as set forth at http:// nrs.harvard.edu/urn-3:HUL.InstRepos:dash.current.terms-of-use\#LAA

\section{Share Your Story}

The Harvard community has made this article openly available.

Please share how this access benefits you. Submit a story.

\section{Accessibility}




\section{Jon Elster, Alexis de Tocqueville: The First Social Scientist \\ Review for Perspectives on Politics by Cheryl Welch}

One of the central mechanisms that Jon Elster finds in the analytical scaffolding underlying Tocqueville's Democracy in America is the spillover effect, a pattern of habit formation in which behaviors followed in one sphere of life are replicated in others. Perhaps Elster is particularly sensitive to this effect because his own intellectual life has been defined by spillovers - the carry over of patterns of explanation from one disciplinary sphere to another. Unlike the coalescing behaviors that Tocqueville observes to occur almost spontaneously among people occupying multiple spheres, however, the illuminating spillovers in Elster's work originate in his own imaginative intellect and deliberate border-crossing. Elster's ease in traversing the fields of economics, political science, philosophy, psychology, and history is perhaps unrivalled in contemporary social science, and his achievement has been to transport foundational explanatory theories into new territories. Thus there are always two audiences for Elster's work: those interested in the philosophy of social science and in the heuristic payoff of following him across borders, and those on home ground who are invited to see their subject in new ways. Both have cause to welcome his latest book, Alexis de Tocqueville: the First Social Scientist.

The most important disciplinary spillover for which Elster has been responsible is the export of assumptions developed by economists and decision theorists into other social sciences. In the process of explicating the central assumptions of rational choice theory, he has worked and reworked a few core principles - methodological individualism; the proper nature of social science explanations (in particular the 
importance of mechanisms over laws, of plural causation, and of the differences between causal, functional, and intentional explanations); and the need to go beyond preferences as given. ${ }^{1}$ Elster is fascinated by Tocqueville because he finds in him a kindred spirit whose affinities on these core principles underlie the claim that Tocqueville was in fact the "first social scientist." One of the contributions of the book, then, is to use a wideranging discussion of Tocqueville's major works to promote the virtues of a particular view of the scope and reach of social science.

Take methodological individualism. Elster has long argued that focusing on individual desires, preferences, and decisions is essential to explanations in the social sciences and that such a focus is compatible with recognition of structural constraints on choice. Although physical, normative, or institutional constraints act as an initial filter limiting the set of possible human actions in a given situation, a second filter results in the choice of one particular course of action among the remaining feasible options. Adequate explanation in the social sciences, Elster insists, must include a detailed examination of this second filter. ${ }^{2}$ Hence the great appeal of rational choice theory, which offers a general account of how agents choose among possible options. It is not only that Tocqueville recognizes just this filtered situation, in which we are both shaped by the mores and laws bequeathed by history and in turn shape these for future generations by the choices open to us, but also that Tocqueville's work is studded with a vast array of fertile hypotheses about how actors in fact choose among the feasible options.

\footnotetext{
${ }^{1}$ These core ideas have informed an impressive array of substantive policy applications, including welfare economics, constitutional design, and transitional justice.

${ }^{2}$ This formulation appears in Elster, Ulysses and the Sirens: Studies in Rationality and Irrationality (Cambridge: Cambridge University Press, 1979, 1984)
} 
In Elster's hands, which extract from Tocqueville's texts “a conceptual framework that seems consistent with the texts while being occasionally more explicit and elaborate than his statements" (47), Tocqueville becomes a spokesman for focusing on the micro foundations of choice rather than the macro perspective of laws. Much of Alexis de Tocqueville: the First Social Scientist focuses on the "enormously creative" (9) articulation in Democracy in America of middle-range mechanisms useful for understanding those micro foundations. Among them are the spillover, compensation, and satiation effects; patterns underlying conformism; and the complex interactions among desires, opportunities, and capacities. These mechanisms are not law-like rules under which individual cases are subsumed, but rather shrewd conceptualizations of possible causal patterns that are heuristically valuable to social scientists who wish to build adequate explanations. Elster finds Tocqueville—unlike Marx and Durkheim— relatively innocent of the sins of teleology and functionalism, and also relatively pure when it comes to imputing intentions without evidence. Thus he emerges as an extraordinarily useful resource for creating a defensible account of why a complicated social outcome in fact occurred - whether in situations of equilibrium (as in Democracy in America) or cases of dynamic social change (as in the Old Regime and the Revolution and the Recollections.)

Finally, the mechanisms that Elster locates in Tocqueville's work cluster in areas in which rational choice theory has been weak, namely in considering how preferences are formed and transformed in institutional settings and in explaining how imperfections in rationality (such as emotion, habit, impulsiveness, and the propensity to lie to ourselves) influence the way we choose the alternatives open to us. Twenty years ago 
Elinor Ostrom wrote that "history, institutions, and cultural traditions will play a more significant role in the evolution of rational choice theories in the future than they have in the past," ${ }^{3}$ suggesting that all good social scientists must be able to negotiate the difficult grey area between empirical work — of many kinds — and formal theories of rationality. It is this terrain for which Elster successfully appropriates Tocqueville as guide, using him as a source of illuminating examples that point out beckoning avenues of future research. His intention, despite the title, is not to make Tocqueville a precursor of rational choice theory, but to make him a pioneer of the kind of fine-grained analysis that so many rational choice theorists eschew. I confess to doubting whether much rests on the red herring that Tocqueville was the "first social scientist." Such a claim is likely to lead to inconclusive debates about claims to priority and about whether Tocqueville, like Monsieur Jourdain, was speaking in prose without knowing it. Elster, who has written so well about the fallacies of imputing intention, admits that he can't prove his hunch that Tocqueville deliberately deployed his mechanisms and then hid the evidence out of aristocratic disdain for revealing the sweat behind his labors. I suspect that other longtime readers will have different hunches about Tocqueville's intentions.

Let me turn now to those other long-time readers, the second audience for Alexis de Tocqueville: The First Social Scientist. After many years of the transatlantic Tocqueville revival, there is a flourishing industry in Tocqueville studies. How ought these scholars to respond to Elster's book, which could have been called Making Sense of Tocqueville? Despite the greater accuracy of such a title, one can immediately see its

\footnotetext{
3 "Rational Choice Theory and Institutional Analysis: Toward Complementarity," The American Political Science Review 85:1 (March 1991), 242.
}

Welch review of Elster - p. 4 of 10 
drawbacks. Tocqueville scholars are likely to count it a point in Elster's favor that he recognizes Tocqueville as a social science great—although they might not agree on the reasons alleged for greatness. But they would (and probably will) bristle either at the thought that Tocqueville is so muddled that he needs Elster to make sense of him, or at the implication that the vast secondary literature—ignored by Elster—hasn't already made quite a bit of sense. I want to defend Elster from these incipient critiques and to urge that Tocqueville scholars open themselves up to the bracing experience of reconsidering familiar texts through the sharp eyes of an observer who deliberately puts himself outside the paradigms of conventional scholarship (a very Tocquevillean thing to do, after all).

Because Elster always takes his interlocutors seriously, cutting into their arguments with painstaking precision, his ambition to take on the corpus of Tocqueville's major works is a kind of homage. He notes that coming to Democracy in America after being immersed for more than a decade in studying the social sciences was so thrilling and unsettling an experience that he literally had to pace. What excites Elster are "the moving parts of the argument" (138) rather than Tocqueville's larger normative and political goals. But it is in part the brilliance and opacity of these moving parts that has stimulated thought in generations of readers. A mysterious alchemy of political psychology and the comparative method, Tocqueville's mode of argumentation generates in the reader a sense that one now "understands" a complex social system or event. In the best sections of Elster's book, the synergy of two minds colliding and colluding reveals the properties of that distinctive fusion. Elster's dissection of the spillover, compensation, and satiation (or crowding out) effects and of the notion of reciprocal causation make it 
impossible to read Democracy in America in quite same way. One does not have to agree with Elster to read him with profit. For example, although one might disagree with some of his discussion of egoism and individualism, his analytical clarification that egoism has two possible antonyms - altruism and foresight — is a the kind of small analytical tour de force that seems obvious only after someone has done the hard thinking of sorting things out. Elster's book is filled with such pearls.

Elster's decision to forego all interaction with the secondary literature is also-in my view—defensible. There are others who have focused on the analytical ligaments of Tocqueville's narratives and many who have written about Tocqueville with deep insight and sympathy. We might be the richer for listening to Elster converse with some of these voices, but he is surely correct that to have done so would have been a major distraction. Elster's method of engaging with other scholars is to zero in on fine distinctions, to shake their statements until all the meanings that he can possibly imagine have been dislodged, and then critically to assess the fallout. It is enough to ask us to follow him in this sort of head to head combat with Tocqueville without taxing us with ancillary battles.

For Tocqueville scholars, then, the contribution of Elster's book does not lie in the persuasiveness of one or another claim, but rather in the clarity and provocation of his textual analysis: fine-grained enough and nuanced enough to force them to reexamine what they thought they knew. Questions and quarrels, of course, will remain. Here are a few that are likely to surface.

Elster is so unrelenting in his chronicle of Tocqueville's contradictions that the litany (consisting of examples of varying degrees of persuasiveness) begins to wear on the reader and to raise the question of Elster's own motivation. It cannot be disputed that 
Tocqueville is an ambiguous writer, often careless with key terms. Elster's plausible suggestion that "he might have probed less deeply had he been more concerned with consistency" (5) has been made by others. And much Tocqueville scholarship consists in speculation about how paradoxes or contradictions might be resolved by putting his apparently conflicting statements in a wider context. But Elster's accumulation of evidence of contradiction sometimes takes on the quality of an accusatory brief that detracts from his main point by turning the reader into a defense attorney. For example Elster finds a central contradiction between Tocqueville's statement that "in most activities of the mind, the American relies solely on the effort of his own individual reason" and his statement that "in ages of equality. . . the disposition to believe in the mass increases" $(4,29)$. But Tocqueville elsewhere supplies a chain of reasoning that links the two statements and that he doubtless expects the reader to insert. ${ }^{4}$ One way to resolve Tocquevillean contradictions, then, is to insert a chain of explanatory links suggested elsewhere in the text. Another is to recognize that statements refer to distinctive situations: one the result of a single unimpeded tendency, the other a result of the interaction of countervailing tendencies. For example, Elster notes that Tocqueville both asserts and denies the capacity of democratic citizens to be motivated by the longterm consequences of their present choices. But exegetical charity fortified by Elster's own astute analysis of Tocqueville's use of mechanisms surely demands that we assume that there may be a tendency to satisfy short-term self-interest that can under other conditions be counteracted. When Tocqueville says democratic citizens myopically seek

\footnotetext{
${ }^{4}$ It goes roughly like this: (1) the first impulse in democratic times is to look only to one's own reason; (2) because reason provides no real certainty, anxiety or restlessness ensues; (3) this mental discomfort leads to a search for definitive authority to alleviate the anxiety; (4) given that traditional authorities (aristocratic, monarchical, religious) have decayed in democratic societies, only the opinions of one's semblables remain; (5) thus the disposition to believe in the mass increases.
}

Welch review of Elster - p. 7 of 10 
their short-term interests, he is isolating one explanatory "mechanism." When he says Americans delay gratification, he is referring to an equilibrium reflecting the converging effects of several "mechanisms" that have transformed this preference. And why is there a contradiction (25-26) between asserting that Americans love to point out how their selfinterest coincides with the public interest (reflecting the equilibrium state in which selfinterest is properly understood) and asserting that they seek to hide egoistic motives (a mechanism that contributes to that equilibrium state by suppressing interests improperly understood)?

I suspect that Elster's carping on Tocqueville's contradictions has its source in disappointment that Tocqueville does not draw the same conclusion as he does from one of their shared assumptions, namely that human reasoning powers are less than robust. Elster quite admirably concludes that precisely because of our mental fallibility we ought to strive for the greatest clarity and self-consciousness about how we think and to communicate this hard-won knowledge as lucidly and honestly as possible to readers. Tocqueville had a different relationship to his audience, based on his hope to modify their preferences and persuade them to act, a goal for which he was willing to sacrifice transparency. ${ }^{5}$

A second unsettling tendency in Alexis de Tocqueville: The First Social Scientist is a cavalier dismissal of those aspects of the text in which Elster himself is not interested. It is not only that he ignores the secondary literature on such matters, but appears pre-emptively to strike such discussions from the universe of worthwhile discourse. Elster claims, for example, that Tocqueville was "not a major political

\footnotetext{
${ }^{5}$ I'm inclined to believe Laurence Guellec that this relationship - at least in Democracy in America-- was based more on a particular kind of democratic hope rather than aristocratic disdain. See her Tocqueville et les langages de la démocratie (Paris : Champion, 2004).
}

Welch review of Elster - p. 8 of 10 
thinker," citing as an indicator that Rawls fails to cite him in A Theory of Justice. Rawls doesn't mention Montaigne, Montesquieu, Diderot, Voltaire, Helvetius, Sieyès, or Comte either, and mentions Rousseau only rarely, but we are hardly justified in concluding anything about the quality of French political thought from those omissions. Similarly, while Elster finds Tocqueville insightful on the psychological and social effects of religion, he finds him arbitrary and "sophomoric" (46) on its content. I think this judgment would be a surprise to those who take as their subject Tocqueville's religious sensibility as well as his sociology of religion. ${ }^{6}$ It is not that Elster should be expected to read or comment on this literature, but that he is unjustified in rejecting out of hand the possibility that reading Tocqueville through the sophisticated lenses of either theology or history might be able to make more sense out of Tocqueville on religion than Elster's claim that his statements come down to "everything is a little bit like everything else (4)."

Finally, although I have argued that Elster's laser-like focus on the individual moving parts in Tocquevillean argumentation is instructive, even exhilarating, such a focus nevertheless requires its own discipline. Elster doesn't always avoid the pitfalls inherent in looking at arguments retail rather than wholesale. He approvingly quotes Sainte-Beuve's famous criticism that Tocqueville "often seems to have thought before he looked" (4), but Elster sometimes leaps before he looks. For example, amidst a discussion of Tocqueville's penchant for noting the instability of "half-way houses," he quotes Tocqueville's observation that "between the extreme inequality created by slavery and the complete equality to which independence naturally leads, there is no durable intermediate state." From this statement, Elster jumps to the conclusion that "Tocqueville

\footnotetext{
${ }^{6}$ The works of Agnes Antoine and Lucien Jaume come to mind. See Antoine, L'impensé de la démocratie : Tocqueville, la citoyenneté et la religion (Paris : Fayard, 2003); Jaume, Tocqueville : les sources aristocratiques de la liberté : biographie intellectuelle (Paris: Fayard, 2008).
}

Welch review of Elster - p. 9 of 10 
would have been surprised by the perpetuation into the present of the de facto inferiority of descendants of slaves.' (112). But if one considers the larger context of Tocqueville's discussion of caste and race prejudice—in Democracy in America and in his writings on European slavery — it is quite clear that what would have surprised him would have been the persistence of de jure inferiority; de facto inferiority would have been no surprise. Indeed he argues that it may be expected to persist in America, and suggests it might even be endogenous to democracy itself.

Despite his penchant for ignoring or dismissing matters outside the circle of his current intense preoccupations (or perhaps because of it - "he might have probed less deeply had he been more concerned with charity"), Elster has written a path-breaking book. It not only serves the interest of the appropriator by mapping some of the frontiers of social science, but transforms the appropriated landscape. Tocqueville's texts have been dragooned into the service of many ideological and political and academic points of view not entirely his own, but rarely with such penetrating insight and verve.

Welch review of Elster - p. 10 of 10 